of the total mass-that a whole galaxy might be disrupted and scattered.

1 Giacconi, R., Gursky, H., Paolini, F. R., and Rossi, B. B., Phys. Rev. Letters, 9, 439 (1962)

2 Giaccuni, R., Gursky, H., Paolini, F. R., and Rossi, B. B., Phys. Rev. Letters, 11,530 (1963).

'Bower, S., Byran, E. T., Chubb, T. A., and Friedman, H., Paper presented at the one hundred and fifteenth meeting of the American Astronomical Socioty, Washington, D.C. (1963).
${ }^{4}$ Chiu, H. Y., Supernovae, Neutrinos, and Neutron Stars (preprint from Princeton Institute for Space Studies, New York, 1963.)

${ }^{5}$ Morton, D. C., Neutron Stars as X-ray Sources (preprint from Princeton University Observatory, 1964).

${ }^{6}$ Oppenheimer, J. R., and Volkoff, G. M., Phys. Rer., 55, 374 (1939).

" Saakyan, G. S., Soviet A. J., 1, 60 (1963).

${ }^{8}$ Hoyle, F., and Fowler, W. A., Astrophys., 132, 565 (1960).

${ }^{9}$ Ginzburg, V. L., Doklady Acad. Sci., U.S.S.R., No. 1, 156 (1964).

${ }^{10}$ Hoyle, F., Fowler, W. A., Burbidge, G. R., and Burbidge, E. M., Astrophys. J., 139, 909 (1964).

\title{
OBITUARIES
}

\section{Prof. James Franck, For.Mem.R.S.}

Prof. James Franck died on May 21 at the age of eighty-one years. Born in Hamburg on August 26, 1882, Franck went to school there with indifferent success-as he was fond of relating-because he had trouble with classic languages. $\mathrm{He}$ began to study chemistry and geology in Heidelberg, but soon turned to physics and moved to Berlin where he graduated as Dr.Phil. in 1906, with a paper on ion mobility in gases. In 1907 he became research assistant to Prof. $H$. Rubens, in whose colloquia I first met him in 1908. I had the great good fortune to win his friendship and that of his family and to retain it for nearly sixty years. Only recently I was able to spend some weeks with Franck, visiting old friends together all over Europe, until a few days before his sudden death in Göttingen, on May 21.

In the First World War Franck went out as a private, was wounded, decorated and returned as a lieutenant. He was then assigned to a group led by the chemist F. Haber, who later, in 1918, made him a division head at the Kaiser-Wilhelm Institute for Physical Chemistry in Berlin-Dahlem.

How well I remember his famous lecture on May 22, 1914, "On the Excitation of the Mercury Resonance Line 2536 A by Electron Impact" in which he reported his joint work with Gustav Hertz, which gave strong support to Bohr's new theory of the atom. Einstein said to me: "It's so lovely, it makes you cry !" Many a discussion between Franck and Otto Stern about those experiments I have listened to during the War years, whenever Franck happened to be in Berlin.

In 1920 Franck was called to a chair in Göttingen. Habor's farewell speech - at a party which Otto Hahn and I arranged-ended with the words: "There are three stages in the life of a scientist: becoming, being and representing; may representing come easy to you". I think Franck did not enter that last stage until a few months before his death, and it was not easy for him, despite the many honours that have come his way, among them the Nobel Prize in Physics in 1926 jointly with Hertz, the Max Planck Medal in 1953, the Rumford Medal in 1955, membership in many learned societies, and the election, in March 1964, as Foreign Member of the Royal Society.

Göttingen saw Franck's happiest and most fruitful period; he remained attached to it, received its honorary citizenship in 1953, and it is an odd turn of fate that he died there. There he did all his work on the transfer of energy in molecular collisions, as in the processes called quenching and sensitized fluorescence. Franck discovered the methor of determining thy heat of dissociation of diatomic molecules from band spectra by extrapolating the vibrational levels. His discussion of the coupling between electron transitions and vibrational motion led him to formulate the principle which was later put in wave-mechanical form by Condon and is known as the Franck-Condon principle. Thus the intensity distribution in band spectra and the existence of continuous molecular spectra came to be understood. The influence of those ideas has been far-reaching, particularly in photochemistry. His many pupils, still attached to Franck in affection and devotion, include such famous names as Blackett, Condon, Kopfermann, Kroebel, Maier-Leibnitz, Oppenheimer and Rabinowitch, to mention some of them.

Those happy days ended when Hitler came to power. When the racial laws were announced, Franck published a courageous open letter in which he resigned his chair. In view of his distinguished war service he might have been allowed to stay, but he did not wish to serve under a Government which treated his fellow Jews as outcasts. After an interlude at Copenhagen, with Niels Bohr, he went to the United States, first to the Johns Hopkins University and then to the University of Chicago, as professor of chemistry. Here his efforts were devoted to the elucidation of the most important of all photochemical reactions, the photosynthesis performed by green plants. It is a borderline problem between physics, chemistry and biology, and one of appalling complexity. Franck's last paper on that subject, in collaboration with J. L. Rosenberg, went to press only a few weeks before he died.

During the War he interrupted his own work for two years to direct the Chemistry Division of the Metallurgical Laboratory of the University of Chicago, a part of the Manhattan Project. He saw it as his duty to help develop a nuclear weapon as long as Hitler might be doing the same. But he felt strongly that the United States should not be first in using it, and other scientists felt similarly. Two months before Hiroshima, a joint letter which became known as the "Franck Report" was sent to the U.S. Secretary of War, Henry L. Stimson, presenting strong and wise arguments against the unannounced use of that dreadful new weapon and suggesting that its power be demonstrated by publicly exploding it over an uninhabited area. Perhaps the nuclear arms race could have been avoided if that letter had been heeded.

Franck enjoyed talking about his problems, not so much to explain them to others as to clarify his own mind. Once a problem had aroused his interest he was completely captivated, indeed obsessed by it. Common sense and straight logic were his main tools, together with simple, mostly home-made apparatus. His research followed an almost straight line, from his early studies of ion mobilities to his last work on photosynthesis; it was always the energy exchange between atoms or molecules that fascinated him.

Franck was equally interested in people. His kindness and generosity, not only to his friends and family but to everybody who needed help, were known to all who knew him. He was the most lovable of men because he loved people; kindness shone from his eyes. There must be many beside myself who now feel they have lost one of their best friends.

I wish to thank O. R. Frisch and H. G. Kuhn for valuable help in writing this notice. LISE MeItren

\section{Prof. Isadore Fankuchen}

The death of Prof. I. Fankuchen on June 27 at the age of fifty-nine leaves a great gap among crystallographers in the United States and particularly, also, in Britain. He was a figure very well known and loved in both countries. 
His life shows him as a man devoted to research and teaching in his chosen field of erystallography. Educated at the Cooper Union, he passed on to Cornell University and thence to various other appointments in the United States. Ho came to England to work with Sir Lawrence Bragg at Manchester in 1934. He had already started his interest in erystallography, although fundamentally he was a physicist, and it was the physical interest rather than the chemical or biological that inspired his work. $\mathrm{He}$ found that in X-ray investigations he was able to apply the physies in more and more refined ways to problems of interest in industry and biology.

From Manchester, he joined me in Cambridge at the very exciting time, in 1936, when the first protein crystals were being examined by X-rays. His point of entry was the exanaination of the sterols which, in the form of vitamin $D$ and its analogues, has just come into biological and pharmacological interest. His earliest work was on the structure of the uranyl compounds and he might well have gone on with this, for he was able to detect by the somewhat primitive methods of the time the presence and strueture of the uranyl complex, $\mathrm{UO}_{2}$, as an independent element in the uranium salts. Here he cooperated with Dr. Dorothy Crowfoot and me in an extensive investigation reported in the chemistry of the steroids (Phil. Trans. Roy. Soc., A, 239, 135; 1940).

However, very soon after ho arrived at the Cambridge laboratory his interest was diverted to the first examination of tobaceo mosaic virus solutions, prepared by Bawden and Pirie. These turned out to be something quito different from anything that had been examined before; they are composed of long particles with a strong tendency to parallel packing which we now know is typical of the rod-shaped viruses. Before the development of the electron microscope this all had to be worked out by X-ray and optical methods.

Fankuchen threw himself into this examination. He excelled in the devising of apparatus specially tailored for the purpose. One problem was that of examining the liquid crystals at very low angles, and for this monochromatic X-rays were essential. $\mathrm{He}$ devised an X-ray monochromator made of a pentaerythritol crystal sliced in such a way that it could give a very narrow beam of strictly monochromatic radiation of high intensity. With this he investigated the variation of the photographs for tobacco mosaic virus solutions where the mutual distance between the rod-like particles was a function of the ionic strength, the $p H$ and the dilution of the solutions. This examination dealt, not so much with the virus itself, but with the long-range forces between virus-like particles and, indeed, any kind of colloidal particles in solution. His work here was finally recorded some years later in the X-ray and crystallographic studies of plant virus preparations (J. Gen. Physiol., 25, 111; 1941).
In 1938, Fankuchen left Cambridge and came to Birkbeck College, London, where I had just become professor of physics, and continued his virus investigations. The War intervened and he returned to the United States where he was later appointed professor of physics in the Polytechnic Institute of Brooklyn, a post which he held until his death.

During the War he took an active part in the investigations coicerned with the use of snow and ice for military tactics, particularly in the project for airborme snow vehicles (weasels) and for the necessary studies to set up the Habakkuk ice ship which was conceived but never built on the full scale.

It was at Brooklyn Polytechnic, an extremely democratic, lively organization, that "Fan" (as he was known to all) found his true vocation as a teacher and director of research. The great growth of the use of X-ray analytic methods in the United States, particularly in industry, is to a very large measure due to his inspiration. He was able to imbue generations of students with the same devotion to the subject he himself had. This was not only in the Polytechnic itself, but also at Wocds Hole in what he called his "Summer Clinics", where every year ho taught a set of volunteers from industry in a fortnight all they needed to know of $\mathrm{X}$-ray method. Fankuchen thus played a large part in spreading the ideas of crystallography and the benefits of crystallography to American industry, where it is more securely based than it is in Britain.

He was also extremely active in promoting the organization of erystallography in the United States and internationally, being one of the founders and, ultimately, the president of the American Crystallographic Association. He became the chairman of the National Research Council Committee on X-ray Crystallography.

Not only was he a devoted teacher, but he was a strongly critical supervisor; no shoddy work was to be tolerated. He further demonstrated this in his work as an editor of the Acta Crystallographica, the international crystallographic journal. Fankuchen helped greatly to strengthen and perpetuate the links between British and American erystallography. He was one of the effective founders of the International Union of Crystallography in 1945.

He will be remembered not so much for his scientific achievements as for his personality and inspiration. His ebullient good humour, friendliness and helpfulness, and his zest for life, made him one of the best-loved figures in American science.

Fankuchen died as he had lived. Stricken by cancer in 1962 , he continued, in spite of two operations, all his lecturing work at Brooklyn and carried out his "Summer Clinie". He gave the last three-hour lecture at this Clinic on June 24 and then collapsed. He was taken to hospital and died only three days later, a life well spent. He leaves behind a wife and son. J. D. Bernal

\section{NEWS and VIEWS}

\section{Physical Chemistry in the University of Oxford:}

Prof. R. E. Richards, F.R.S.

ON October 1, Dr. R. E. Richards will succeed Sir Cyril Hinshelwood as Dr. Lee's professor of chemistry at Oxford (see p. 958 of this issue of Nature). Since 1947 he has been a Follow and Tutor of Lincoln College, in which eapacity he followed the late N. V. Sidgwick. Since 1948 he has worked, first as a University demonstrator and later as reader, in the Department over which, in its recently somewhat reorganized form, he will preside. Dr. Richards was educated at Colyton Grammar School, Dovon. Ho was an Exhibitioner of St. John's and later Senior Demy of Magdalen College. In 1954 he was awarded the Corday-Morgan
Medal of the Chemical Society and in 1955 he was a Research Fellow at Harvard. He was elected to the Royal Society in 1959. His first research work was in the field of infra-red spectroscopy, but for the past fifteen years or so he has worked mainly on magnetic phenomena. It soon became evident that measurements of nuclear magnetic resonance were eapable of throwing a great deal of light on very varied chemical problems, and Dr. Richards has been one of the foremost leaders in its development and application, winning thereby world-wide recognition. Dr. Richards takes over the Department at a moment of considerable expansion of its already vigorous activity, and it is fortunate to be passing into the charge of one with such eminent qualities. 